\title{
Islamic Education in Southeast Asia
}

\author{
Adib Rifqi Setiawan \\ $\Lambda$ lobatnic Islamic Studies ( $\Lambda \mathrm{IS})$ \\ Jl Kudus - Colo, km. 19, Pandak 001/003, Colo, Kudus, 59353, Indonesia \\ adibrifqisetiawan@gmail.com
}

\begin{abstract}
Islamic Education in Southeast Asia reflects the diversity of Islam in that part of the world and of course plays a central role in shaping and transmitting the region's religious traditions. this work concludes that Southeast Asia has an extraordinarily large and well-developed structure of Islamic education that can be a resource of critical importance in the ongoing war of ideas within Islam.
\end{abstract}

Keywords : Islamic Education; Southeast Asia;

\section{Introduction}

Islamic Education in Southeast Asia reflects the diversity of Islam in that part of the world and of course plays a central role in shaping and transmitting the region's religious traditions. Therefore, before discussing the structure of Islamic education in Southeast Asia, it might be worth outlining the politico-religious and ideological context in which Islamic educational institutions are embedded. ${ }^{1}$

\section{Southeast Asian Islam}

One of the most striking characteristics of Southeast Asian Islam as a whole is the relative absence, until the latter part of the twentieth century, of extremist Salafi or Wahhabi variants of the religion. Moreover, Southeast Asian Islam remains extraordinarily diverse-a reflection of the fact that the majority of Muslims throughout the region incorporate local cultural, ethnic, and linguistic traditions into their practice of Islam. This tendency — which is referred to as "traditionalism" in Indonesia-is quite removed in spirit and practice from Wahhabi severity and intolerance, and is especially strong on the Indonesian island of Java, particularly East Java.

For the most part, traditionalist Muslims in Southeast Asia adhere to the Syafi ' $i$ (in Arabic, Shafi'i) mazhab (school of jurisprudence). Indonesian traditionalists are represented by the Nahdlatul Ulama (Awakening of the Ulama-NU), the largest social welfare organization in the Muslim world with a claimed membership of over 40 million. The organization was founded in 1926 by a group of kiai (traditional Islamic teachers), who were alarmed by the inroads made by modernists. NU seeks to conserve the Javanese tradition in the organization's religious beliefs and practices_-for instance, the practice of ziarah kubur (the visiting of graves), in which contact is established with the spirit of the deceased. ${ }^{2}$

\footnotetext{
${ }^{1}$ (Mahmada, 2004)

${ }^{2}$ For instance, at the haul (anniversary of death) of an important kiai (religious teacher) in East Java in 2001, thousands of religious students jointly performed two million recitations of the chapter Al-Ikhlas and several hundred of the entire Qur'an, generating a great amount of merit that added to the spiritual power that the deceased was able to exert from the grave. (Bruinessen, 2002)
} 
NU's original constitution committed it to a range of religious, social and economic activities, but first and foremost was the promotion of religious education. The authority of the ulama and the strength of the organization are rooted in thousands of NU-affiliated pesantren (religious boarding schools). Although representing traditionalist Islam, the NU leadership has endeavored to adapt to modern conditions. Under the chairmanship of Abdurrahman Wahid in the 1980s and 1990s, the curriculum in the NU pesantren was reformed significantly, and secular subjects were taught in conjunction with traditional religious subjects. The NU leadership also worked through associated foundations and research institutes to promote a democratic civil society and to reconcile Islam with Indonesian nationalism and democracy. ${ }^{3}$

The second important tendency within Southeast Asian Islam is modernism. In Indonesia, modernism is part of a movement that began at the turn of the 20th century. It was influenced by the ideas of such thinkers as Jamal al-Din al-Afghani and Muhammad Abduh and aimed to purify Indonesian Islam of what was considered to be heterodox practices. The founders of Muhammadiyah, established in 1912 as the institutional expression of the Indonesian modernist movement, wanted to banish the "superstition" associated with some of the practices of traditionalist Indonesian Islam, and also to counterbalance the development of Catholic and Protestant missions. Today, Muhammadiyah is heavily involved in education, health care, orphanages, and other social services with Islam as its ideological and moral basis.

Unlike conservative Salafis, Indonesian modernists believe in adjusting syariat law (in Arabic, sharia) to the contemporary world. In the view of Muhammadiyah chairman Ahmad Syafii Maarif, Islamic law needs to be reformed, since in many cases it is no longer contextual to modern conditions. ${ }^{4}$ In recent years there has been a convergence, at least at the level of the elites, of NU and Muhammadiyah attitudes and religious practices. Some NU members who studied in Middle Eastern universities have become more receptive to the principle of ijtihad (independent reasoning), which is central to modernist Islam. The new discourse on gender equality has also gained greater acceptance within NU, and rejection of polygamy is now very strong among the younger generation. The Muhammadiyah, too, has undergone some significant transformation. In the past, it was opposed to Sufi practices. Today, however, increasing numbers of Muhammadiyah members practice Sufism. Despite this convergence, important differences between the two groups remain, especially between their respective modes of political engagement: The Muhammadiyah focuses on promoting religious renewal through education and social services, while Nahdlatul Ulama is focused more on traditional education and practices. ${ }^{5}$

This convergence of the two pillars of moderate and progressive Islam in Indonesia is juxtaposed against a trend toward radicalism in other sectors of Indonesian Islam. These radical interpretations are associated with what Islamic activist Whasvi Velasufah calls the "Modern Islamic Movement," which emerged in the 1980s and 1990s as part of the worldwide wave of Islamization. ${ }^{6}$ These groups include Hizbut-Tahrir and Jamaah Tarbiyah, which both support the establishment of a pan-Islamic caliphate, the Jamaah al-Ikhwan alMuslimin Indonesia (Indonesian Muslim Brotherhood), and other extremist groups that emerged in the immediate post-Suharto period.

\footnotetext{
3 (Ramage, 1999)

${ }^{4}$ (Maarif, 2015)

5 (Octaviani \& Rosiana, 2016)

${ }^{6}$ (Velasufah, 2019)
} 
As in the rest of Southeast Asia, the influx of Saudi money and ideology in Indonesia has been an important engine of this radicalization. The Saudi religious affairs office in Jakarta finances the translation from Arabic to Bahasa Indonesia of about one million books a year. It also offers scholarships to Indonesian students for study in Saudi universities. ${ }^{7}$ Arab influences are also exerted through the Hadrami Diaspora in Southeast Asia. ${ }^{8}$

Islamic extremism in Indonesia is often associated with clerics of Arabic origin. For example, Ja'afar Umar Thalib, leader of the now disbanded Laskar Jihad; Abu Bakar Ba'asyir and the late Abdullah Sungkar, founders of Jemaah Islamiyah; Islam Defenders' Front head Muhammad Habib Rizieq, and others. Some Islamic scholars attribute the moderate character of Indonesian Islam to their perception that Indonesia is the least "Arabized" of the major Muslim countries. ${ }^{9}$

Islam in Malaysia has also been deeply influenced by traditionalist practices and beliefs. However, in modern times, Islam in Malaysia has become more homogeneous and orthodox than in Indonesia. This is largely the result of the centralization of religious authority under the sultanate system and the role that government has played in defining religious orthodoxy. The development of a centralized religious authority to oversee Islamic affairs in the Malay States began under the British administration. Religious officials were engaged as government functionaries at the state level. After independence, the constitution established the country's nine sultans as the final arbiters in matters relating to religion. ${ }^{10}$ The result was enforced Sunni orthodoxy. Heterodox religious movements, largely tolerated in Indonesia, were suppressed in Malaysia as "cults." On 21 October 1994, for instance, the government accused Darul Arqam, a major Islamic movement, of spreading heterodox teachings, and subsequently banned them and citing the organisation as 'deviant' and 'deviationist'. ${ }^{11}$

Like other Southeast Asian Muslims, the Muslims of the Philippines, who are collectively known as "Moros" or the "Bangsamoro" (literally, the "Moro Nation"), have retained many pre-Islamic beliefs and rituals. Historically, much of the knowledge about Islam among the Moros was handed down from mouth to mouth and was connected with folk beliefs. According to the sociologist Peter Gowing, there was general ignorance of the Qur'an and even of the rudimentary teachings of Islam in the Philippines. After the Second World War, however, the Muslim areas of the Philippines experienced an Islamic resurgence. This resurgence was influenced by the religious revival in neighboring Muslim countries, in particular by the dakwah movement in Malaysia, and by the return of Philippine Muslim scholars from al-Azhar University and other centers of Islamic learning in the Middle East. ${ }^{12}$

\section{The Structure of Religious Education in Southeast Asia}

The public education systems in the Muslim majority countries of Southeast Asia include religious education. In Indonesia, religious education in state-run schools is multi-religious. Every student who belongs to any religions (Islam, Catholic Christianity, Protestant Christianity, Buddhism and Hinduism) is entitled to religious instruction in his or her religion

\footnotetext{
7 (Perlez, 2003)

8 (Setiawan, 2020)

9 (Velasufah, 2019)

${ }^{10}$ (Mutalib \& Kua, 1993, pp. 20-6)

11 (Means, 2009, p. 132)

12 (Horizon, 1974, pp. 212-8)
} 
(although a minimum number of students is required before instruction in a particular religion is provided). If no religious instruction is available in accordance with the student's faith, the student has the right to be excused from religious instruction. Instruction in Confucianism can also be offered as an option in state schools, although Confucianism is not a recognized religion. The religious curriculum is set by the Ministry of Education, in consultation with representatives of the different religious communities.Textbooks are produced by autonomous publishers, but screened by the Ministry. In order to enhance the teachers' knowledge of other religions, the general competence aims for the other religions are cited in the introduction to the curricula for every religion. ${ }^{13}$

In Malaysia, unlike Indonesia, Islam is the official religion of the state, and the only religious instruction provided in public schools is in Islam. It is, however, not mandatory for nonMuslim students to study Islam. In the Philippines there is no state religion and the Constitution provides for the separation of Church and State. The government, however, makes public schools available to church groups to teach moral values during school hours.

Aside from religious instruction in state schools, Islamic education is also provided throughout Southeast Asia at the primary and secondary levels through boarding schools. ${ }^{14}$

In Malaysia and southern Thailand these schools are known as "pondok"; in Indonesia, such boarding schools are known as "pesantren." Indonesia also has Islamic day schools known as "madrasas" (confusingly for Westerners, who associate the term "madrasa" with the boarding schools of the Middle East and South Asia). ${ }^{15}$ The majority of the Indonesia's pesantren are affiliated with the traditionalist NU organization. A smaller number adhere to the modernist doctrines of the Muhammadiyah and Persis organizations, and only a very small minority teaches extremist interpretations of Islam. ${ }^{16}$

In Indonesia, most pesantren and madrasas include instruction in secular subjects in their curricula. ${ }^{17}$ Nevertheless, these institutions have a religious purpose to teach Islam through the reading and rote memorization of the Quran. Successful students are those who are able to recite passages from the Quran in Arabic without mistakes, even though many of these students do not fully understand in Arabic. Senior students at these institutions are taught more complicated Islamic doctrines - for example, Islamic theology, law, and ethics. Since textbooks are largely only available in Arabic, learning the Arabic language and how to translate those textbooks into the local dialect constitutes a major part of the teaching process and is carried out by the teacher with every student individually.In the Indonesian pesantren, students do not have a time limit for completing their education, and they can leave a school when they feel their knowledge of Islam is sufficient. ${ }^{18}$

Indonesia's pesantren are run and often owned by an individual religious teacher. The students are bound in a personal relationship with their headmaster or teacher, who may promote a particular ideology or interpretation of Islam. ${ }^{19}$ Many contemporary pesantren are now providing both traditional Islamic education and modern national education. In addition to the general curriculum, many kiai have found it useful to offer extra courses-(English and

\footnotetext{
13 (OECD \& ADB, 2015)

${ }^{14}$ (Musfiroh, 2017)

15 (Setiawan, 2018)

16 (Setiawan, 2018)

17 (Setiawan, 2020)

${ }^{18}$ (Setiawan, Puspaningrum, \& Umam, 2019)

${ }^{19}$ (Siayah, Conversation with Syarofis Siayah in Malang on 4 October 2019, 2019)
} 
computer science are the most popular) - as well as vocational training in skills such as driving, automobile repair, sewing, small business management, and welding. In part, this is in response to government programs designed to encourage the improvement of human resources. In part, it is a reflection of the fact that skills-training is a time-honored part of pesantren education. Traditionally, students did not pay for their education or lodging but worked for the kiai in exchange for their expenses.

Even with the addition of secular and technical subjects, the main purpose of the pesantren education, as noted above, is to spread Islam. Pesantren values define a modernity quite different from that practiced in the West. The values of Islamic brotherhood and selflessness are seen as safeguards against heartless Western capitalism, and "self-sufficiency" is taught as the ground of individual and the nation continued independence. For individuals, this means that a person should exercise the entrepreneurship that development requires, but controlled by Islamic values. ${ }^{20}$ These values are by no means inconsistent with democracy. Over the past decade, more thanone thousand pesantren have participated in programs aimed at promoting the values of pluralism and tolerance, and at bolstering civil society. In one such program, the pesantren students are taught to run issue-based political campaigns, to conduct elections for student leadership, and to represent their constituency both with pesantren leaders and the local community. ${ }^{21}$

In the rest of Southeast Asia, the structure and curriculum of private religious education is quite different than it is Indonesia. In Malaysia, for example, the Islamist party PAS exercises a strong influence in private Islamic schools. Although the level of militancy in the Malaysian Islamic educational system has never approached that of Pakistan, it has nevertheless worked to sustain the fundamentalist politico-religious movement. In the pondoks of southern Thailand, the national curriculum is taught in addition to Islamic subjects. While in the past the Thai pondoks helped to preserve the local Malay dialect in southern Thailand, instruction is now in Thai, as well as in Arabic, which is needed for the study of the Quran. Nevertheless, as discussed in the next section, pondoks in Southern Thailand reportedly serve as recruitment centers for a violent separatist campaign. In the Philippines, the Islamic schools within the formal education system - that is, those accredited by the state - are generally moderate, but there are a few unaccredited radical madrasas, some of which are funded by the Saudis. ${ }^{22}$

\section{Radical Schools in Southeast Asia}

In Indonesia and Malaysia, a small number of radical Islamic schools have served as incubators for the violent fringe of the Islamist movement in Southeast Asia, including the regional terrorist organization Jemaah Islamiyah and its political front, the Majlis Mujahidin Indonesia (MMI). Other schools, such as the Yala Islamic College in southern Thailand, have been conduits for Wahhabi influence.

According to Southeast Asia terrorism expert Zachary Abuza, the Indonesian security services believe that presently 60-100 pesantren serve as centers of JI recruitment and ideological indoctrination. ${ }^{23}$ In this category of terrorist incubators are the Pondok al-Mukmin in Ngruki, Sukohardjo in Solo (Surakarta), Mutaqin in Jabarah, Dar us-Syahadah in Boyolali,

\footnotetext{
${ }^{20}$ (Tan, 2014)

21 (Siayah, 2010)

22 (Velasufah, 2019; Musfiroh, 2017)

23 (Djafar, 2018 , pp. 58-9)
} 
all in Central Java; al-Islam in Lamongan, East Java; and the Hidayatullah network in East Kalimantan and Sulawesi. Jaafar Umar Thalib, the leader of the now disbanded Laskar Jihad, administers another pesantren, Ihya as-Sunnah in Yogyakarta. ${ }^{24}$ Although their number is relatively small in a universe with thousands of schools, these radical pesantren have had a disproportionate influence in shaping and propagating radical Islam in Southeast Asia.

The most notorious of these institutions is Pondok al-Mukmin, an educational institution that some have referred to as "the school of terrorists." Pondok Al-Mukmin was established in 1971 by two radical Indonesian figures, Abu Bakar Ba'asyir and Abdullah Sungkar. In 1973 the pesantren moved to its current location in Ngruki, Central Java. From 1978 to 1982, Ba' asyir and Sungkar were imprisoned by the Suharto government on charges of subversion. After their release, the two fled to Malaysia to escape re-arrest. ${ }^{25}$ In Malaysia, Ba'asyir and Sungkar, together with Abu Jibril (alias Fikiruddin, alias Mohamed Iqbal), an Indonesian veteran of the Afghan jihad, established the Tarbiyah Luqmanul Hakiem school in Ulu Tiram, Johor state, modeled on Al-Mukmin. During this Malaysian period, Ba'asyir and Sungkar joined forces with another Indonesian Afghan war veteran and former Ngruki student who was also a member of the al-Qaeda shura, Riduan Isamuddin, alias Hambali, to found the terrorist organization Jemaah Islamiyah (JI).

Ba'asyir, Sungkar and several other exiles returned to Indonesia in 2000, after the downfall of Suharto and his government. Sungkar died soon thereafter of natural causes and Ba'asyir became the emir or spiritual leader of JI, as well as emir of the governing council of the JI's political front, the MMI, which was formally launched in Yogyakarta in 2000. Ba'asyir was arrested following the Bali bombing of October 2002 and charged with treason. He was, however, convicted of lesser charges and sentenced to three years in prison-a sentence that the Supreme Court later reduced to eighteen months (amounting to time already served) in March 2004. Upon his release, Ba'asyir was re-arrested, tried and convicted in March 2005 of conspiracy charges - a crime that carries a maximum term of five years - and sentenced to two and a half years in prison. Ba'asyir's second arrest was on retroactive terrorism charges. Indonesia's Constitutional Court declared the use of the anti-terrorism law retroactively unconstitutional in July 2004, but made an exception for the Bali bombing.

Pondok al-Mukmin's reputation as a seedbed of terrorism is well deserved. The school produced dozens of convicted terrorists linked to three major bombings in Indonesia and at least two dozen smaller terrorist attacks. ${ }^{26}$ Noor Huda Ismail, a graduate of the school, reported that the school taught nothing but an extremist form of Islam. The only music blasting from the speakers was an Arab song about jihad. Printed Arabic calligraphy covered the dormitory walls. One of them read: "Die as a noble man or die as a martyr." Inside the school's walls, he says, anti-Semitism was rampant. In Thursday night public speaking classes, the most popular subject was the threats facing Islam. Speakers often quoted the verse in the Quran that reads: "the infidels and Jews will never stop fighting us until we follow their religion." Ismail reported that days before his graduation the school's faith teacher, Aburrohim (alias Abu Husna), invited him and five other students to join JI. Those who agreed to join received military training in Afghanistan (before the downfall of the Taliban) and at Camp Hudaibiyah in Mindanao. ${ }^{27}$

\footnotetext{
${ }^{24}$ (Mohammad \& Sujoko, 2004)

${ }^{25}$ (International Crisis Group, 2002)

${ }^{26}$ (Coulson, 2017)

27 (Media Indonesia, 2020)
} 
An important component of the broader jihadist network in Indonesia is centered on the island of Sulawesi. This is the Makassar-based organization Komite Pengerak Syariat Islam (Committee for Upholding Islamic Law-KPSI), previously known as the Preparatory Committee for the Upholding of Islamic Law (KPPSI). The armed wing of the KPSI, the Laskar Jundullah, is responsible for a great deal of sectarian violence in the Moluccas and Sulawesi.The KPSI is linked to the MMI and JI through Agus Dwikarna, the head of the Laskar Jundullah and a member of the MMI executive committee. (Dwikarna was arrested at the Manila airport in March 2002 and charged with carrying explosive materials.) According to the International Crisis Group, the head of the KPSI, Abdul Aziz Qahhar Muzzakar, also runs a pesantren in Makassar that serves as the local branch of the so-called "Hiyadatullah network," named after the militant Islamic magazine Hiyadatullah. ${ }^{28}$

In Thailand, the Yala Islamic College, with about 800 students, teaches hard-core Wahhabi beliefs. The college is headed by Dr. Ismail Lufti, a graduate of Riyadh's Imam Muhammad bin Saud Islamic University, and reportedly receives funding from Saudi Arabia, Qatar and Kuwait. ${ }^{29}$ The Thai government believes that a number of Islamic boarding schools in the southern provinces serve as breeding grounds and recruitment centers for militants who are carrying out terrorist attacks in the southern provinces. A number of the Muslim separatists killed in attacks on police and security forces posts on April 28, 2004 were teachers at local Islamic schools. $^{30}$

The reaction of regional governments to these terrorist schools has been somewhat uneven. The Malaysians have shut down the Tarbiyah Luqmanul Hakiem school, as well as another radical school, the Sekolah Menengah Arab Darul Anuar in Kota Baru. In Indonesia, however, Pondok Mukmin and other radical pesantren continue to operate. Until the Bali bombing, many radical and violent groups enjoyed the support of mainstream politicians, such as the former Vice President Hamza Haz, who visited Ba' asyir at his headquarters in the Al-Mukmin pesantren. After the Bali bombing in October 2002, the leaders of Nahdlatul Ulama and Muhammadiyah mounted a joint campaign against terrorism - a welcome change from the passivity of moderates toward the threat of radicalism and violence in the name of Islam. ${ }^{31}$ In Thailand, after the incidents of April 28, 2004, which involved multiple attacks by hundreds of militants on police stations and security posts throughout the southern provinces, and culminated in the storming of the Kru Se mosque in Pattani by the army, causing the deaths of 110 militants who had taken refuge in the mosque, the Bangkok government proposed a large-scale closing of Islamic schools and arrests of teachers accused of advocating violence against the state. ${ }^{32}$

\section{Islamic Universities}

The most extensive and sophisticated system of university-level Islamic education in Southeast Asia - and perhaps in the entire world - is in Indonesia. The Syarif Hidayatullah Islamic University, formerly the Institut Agama Islam Negeri (IAIN) or State Institute for Islamic Studies, is comprised of 47 colleges and universities with over 100,000 students. The

\footnotetext{
${ }^{28}$ (International Crisis Group, 2002)

${ }^{29}$ (Bradley, 2004)

${ }^{30}$ (Liow, 2006)

31 (Mahmada, 2004)

32 (Liow, 2006)
} 
IAIN system draws many of its students from the pesantren since, until years ago, a pesantren education did not provide access to other universities. ${ }^{33}$

The university's overarching aim is to produce tolerant graduates with a modern, "rational Islam" outlook. The university has nine faculties, including a Faculty of Theology (Fakultas Ushuluddin), which includes a Department of Comparative Religion, a Faculty of Sharia (Fakultas Syari'ah) and a Center for Women's Studies. Perspectives of comparative religion have been included in Islamic studies at IAIN, together with interfaith, human rights and gender issues. The IAIN also publishes two noteworthy academic journals, Studia Islamika and Kultur, which publish articles by Indonesian and Western Islamic scholars. According to Amin Abdullah, the rector of IAIN in Yogyakarta, IAIN has long been at the forefront of issues such as interfaith dialogue and at improving overall relations between Islam and the West ("we must explain to the Saudis that they misunderstand the West").

Another major system of Islamic university education is associated with the Muhammadiyah. The Muhammadiyah model of university education is based on the Dutch system, and includes the teaching of religious subjects that reflect, naturally, Muhammadiyah's modernist beliefs and principles. A third Islamic university is the Islamic University of Indonesia. Both the IAIN and Muhammadiyah universities subscribe to democratic and pluralistic values.After the downfall of President Suharto's government in 1998, IAIN developed a civic education course to replace the previously mandatory state ideology courses with a new curriculum designed to teach democracy in an Islamic context. This course has been made mandatory for all students in the IAIN system and has proven so successful that the Muhammadiyah network also developed its own mandatory democratic civic education course.

In Malaysia, the system of Islamic university education has gone a different route. As part of its Islamization program, the Mahathir government established the International Islamic University (IIU) near Kuala Lumpur. As the university's name indicates, its approach to Islamic studies reflects a universalistic interpretation of Islam that is closer to that of religious institutions in the Arab world.

In the Philippines, there are some Islamic colleges, but no Islamic university.The Mindanao State University, a secular institution with nine campuses, has a majority Muslim student body. The main campus of the university and its three branches are within the Autonomous Region in Muslim Mindanao (ARMM) at Marawi City, Datu Odin Sinsuat, Tawi Tawi and Sulu, respectively.There is an Institute of Islamic Studies at the University of the Philippines that conducts research, but in order to receive the required education in Islamic studies required of an alim, a Filipino student must go abroad.

Thailand plans to establish its first Islamic university in 2005. The university will be a branch of Egypt's al-Azhar University. The Thai government will provide most of the funding for the project, but the university will seek financial assistance from outside sources, including from Muslim countries. ${ }^{34}$ This development should be watched, as it is likely to impact the overall political and intellectual dynamic of Islam in Thailand and elsewhere in Southeast Asia.

\footnotetext{
33 (Meuleman, 2005, pp. 283-8)

34 (Pathan, 2004)
} 


\section{Conclusion}

Southeast Asia has an extraordinarily large and well-developed structure of Islamic education that can be a resource of critical importance in the ongoing war of ideas within Islam. These institutions can be expected to keep the Muslim communities in Southeast Asia rooted in their moderate and tolerant values, despite the apparent onslaught of extremist ideology from the Middle East. At a global level, they could serve as the building blocs of a moderate or liberal Muslim international movement to counter the influence of radical Salafi networks.

\section{Acknowledgment}

This work is dedicated to my great friends Arij Zulfi Mufassaroh a.k.a. Ais, of her amazing inspiring dan motivating my daily, nor for her endless shaping my mindset and developing my skill. Happy $24^{\text {th }}$ birthday, Jenong-Pesek.

\section{Work Cited}

Associated Press. (2007, March 18). Attack On Thai School Kills 3 Students. Retrieved April 10, 2020, from CBS News: https://www.cbsnews.com/news/attack-on-thai-schoolkills-3-students/

Bradley, J. R. (2004, May 27). Waking Up to the Terror Threat in Southern Thailand. Retrieved April 10, 2020, from Yale University : https://yaleglobal.yale.edu/content/waking-terror-threat-southern-thailand

Bruinessen, M. v. (2002). Back to Situbondo? Nahdlatul Ulama attitudes towards Abdurrahman Wahid's presidency and his fall. In H. S. Nordholt, \& I. Abdullah, Indonesia in Search of Transition (pp. 15-46). Yogyakarta: Pustaka Pelajar.

Coulson, J. (2017, November 5). Defining “Radical:” The problems and politics of deradicalizing Indonesia's Muslim boarding schools. Retrieved April 10, 2020, from The Institute of Current World Affairs: https://www.icwa.org/defining-radicalproblems-politics-deradicalizing-indonesias-muslim-boarding-schools/

Djafar, A. M. (2018 ). (In)toleransi - Memahami Kebencian \& Kekerasan Atas Nama Agama. Jakarta Pusat: Elex Media Computindo.

Horizon, M. F. (1974). Peter G. Gowing. Quezon City: New Day Publishers.

International Crisis Group. (2002, August 8). Al-Qaeda in Southeast Asia: The Case of the Ngruki Network in Indonesia. Retrieved April 10, 2020, from Crisis Group Asia Briefings: https://www.crisisgroup.org/asia/south-east-asia/indonesia/al-qaedasoutheast-asia-case-ngruki-network-indonesia

Liow, J. C. (2006, July). International Jihad and Muslim Radicalism in Thailand?: Toward an Alternative Interpretation. Asia Policy, 2, 89-108.

Maarif, A. S. (2015). Menimbang Kembali Keindonesiaan dalam Meneropong Masalah Keadilan, Kemanusiaan, Kebinekaan, dan Toleransi. In A. S. Maarif, L. H. Saifuddin, M. A. Abdullah, S. Anwar, A. Azra, H. Ilyas, et al., Fikih Kebinekaan (pp. 20-28). Bandung: Mizan Pustaka.

Mahmada, N. D. (2004, March). Moderate Indonesian Muslim Rejection of the US Attack on Iraq. Kyoto Review of Southeast Asia, 5.

Means, G. P. (2009). Political Islam in Southeast Asia. Boulder: Lynne Rienner Publishers. Media Indonesia. (2020, April 9). Kikis Terorisme dengan Uluran Tangan. Retrieved April 10, 2020, from YouTube Alobatnic: https://youtu.be/B0VEMIVVXls 
Meuleman, J. (2005). The Institut Agama Islam Negeri at the Crossroads. In J. Meuleman, Islam in the Era of Globalization: Muslim Attitudes towards Modernity and Identity. London: Routledge.

Mohammad, H., \& Sujoko. (2004, November 12). Syariat Tak Pernah Padam. Retrieved April 10, 2020, from Gatra: http://arsip.gatra.com/2004-1112/majalah/artikel.php?pil=23\&id=48971

Musfiroh, M. (2017, April 21). Conversation with Maryam Musfiroh in Masjid Agung Garut on 21 April 2017. (A. R. Setiawan, Interviewer)

Mutalib, H., \& Kua, E. H. (1993). Islam in Malaysia: From Revivalism to Islamic State? Singapore: National University of Singapore (NUS) Press.

Octaviani, E. R., \& Rosiana, L. H. (2016, July 9). Conversation with Eny R. Octaviani \& Leily Hardianti Rosiana in Keboen Iboe on 9 July 2016. (A. R. Setiawan, Interviewer)

OECD \& ADB. (2015). Education in Indonesia: Rising to the Challenge. Paris: OECD Publishing.

Pathan, D. (2004, September 23). Al Azhar to Offer Courses in Thailand. Retrieved April 10, 2020, from Yale Global: https://yaleglobal.yale.edu/content/al-azhar-offer-coursesthailand

Perlez, J. (2003, July 5). Saudis Quietly Promote Strict Islam in Indonesia. Retrieved April 10, 2020, from New York Times: https://www.nytimes.com/2003/07/05/world/saudisquietly-promote-strict-islam-in-indonesia.html

Ramage, D. E. (1999). Social Organizations: Nahdlatul Ulama and Pembangunan. In R. W. Baker, M. H. Soesastro, J. Kristiadi, \& D. E. Ramage, Indonesia: The Challenge of Change. Singapore: Institute of Southeast Asian Studies.

Setiawan, A. R. (2018, December 24). Madrasah Tasywiquth Thullab Salafiyyah (TBS) Kudus. Retrieved April 10, 2020, from Alobatnic:

http://alobatnic.blogspot.com/2018/12/madrasah-tasywiquth-thullab-salafiyyah-tbskudus.html

Setiawan, A. R. (2018, March 17). Maryam Musfiroh: An Educator for Our Time. Retrieved April 10, 2020, from Qureta: https://www.qureta.com/post/maryam-musfiroh-aneducator-for-our-time

Setiawan, A. R. (2020, March 1). Pendidikan Literasi Finansial Melalui Pembelajaran Fiqh Mu'āmalāt Berbasis Kitab Kuning. Nazhruna: Jurnal Pendidikan Islam, 3(1), 138159.

Setiawan, A. R. (2020, 4 1). Sharifah Halimah Alaydrus. Retrieved April 10, 2020, from Alobatnic: https://alobatnic.blogspot.com/2020/04/sharifah-halimah-alaydrus.html

Setiawan, A. R., Puspaningrum, M., \& Umam, K. (2019). Pembelajaran Fiqh Mu'āmalāt Berorientasi Literasi Finansial. Tarbawy: Indonesian Journal of Islamic Education, 6(2), 187-192.

Siayah, S. (2010, December 4). Pendidikan di Indonesia?? what happen??? Retrieved April 10, 2020, from Kadar Kualitas Pendidikan di Indonesia: http://sweetybanatnu.blogspot.com/2010/12/pendidikan-di-indonesia-whathappen.html

Siayah, S. (2019, October 4). Conversation with Syarofis Siayah in Malang on 4 October 2019. (A. R. Setiawan, Interviewer)

Tan, C. (2014). Educative Tradition and Islamic Schools in Indonesia. Journal of Arabic and Islamic Studies, 14, 47-62.

Velasufah, W. (2019, September 27). Conversation with Whasfi Velasufah in Omah Kopi on 27 September 2019. (A. R. Setiawan, Interviewer) 